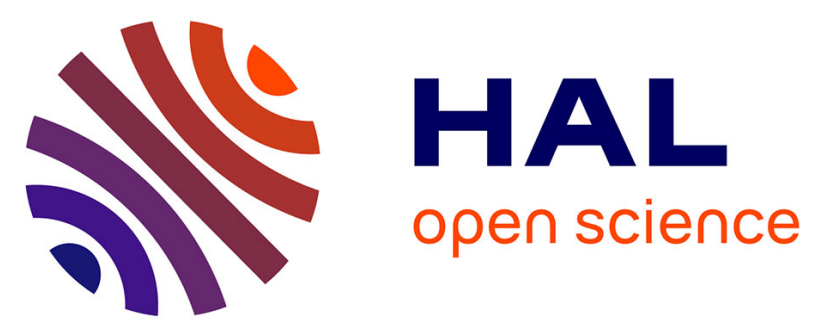

\title{
Speciation of organic fractions does matter for aerosol source apportionment. Part 2: Intensive short-term campaign in the Paris area (France)
}

Deepchandra Srivastava, Olivier Favez, Nicolas Bonnaire, Franco Lucarelli, Martial Haeffelin, Emilie Perraudin, Valérie Gros, Eric Villenave, Alexandre Albinet

\section{To cite this version:}

Deepchandra Srivastava, Olivier Favez, Nicolas Bonnaire, Franco Lucarelli, Martial Haeffelin, et al.. Speciation of organic fractions does matter for aerosol source apportionment. Part 2: Intensive shortterm campaign in the Paris area (France). Science of the Total Environment, 2018, 634, pp.267-278. 10.1016/j.scitotenv.2018.03.296 . ineris-01853335

\section{HAL Id: ineris-01853335}

https://hal-ineris.archives-ouvertes.fr/ineris-01853335

Submitted on 25 Sep 2018

HAL is a multi-disciplinary open access archive for the deposit and dissemination of scientific research documents, whether they are published or not. The documents may come from teaching and research institutions in France or abroad, or from public or private research centers.
L'archive ouverte pluridisciplinaire HAL, est destinée au dépôt et à la diffusion de documents scientifiques de niveau recherche, publiés ou non, émanant des établissements d'enseignement et de recherche français ou étrangers, des laboratoires publics ou privés. 


\section{Speciation of organic fractions does matter for aerosol source}

\section{apportionment. Part 2: intensive short-term campaign in the Paris}

\section{area (France)}

D. Srivastava ${ }^{1,2,3,{ }^{*}, \text { O. Favez }}{ }^{1}$, N. Bonnaire ${ }^{4}$, F. Lucarelli ${ }^{5}$, M. Haeffelin ${ }^{6}$, E. Perraudinn ${ }^{2,3}$, V.

$$
\text { Gros }^{4} \text {, E. Villenave }{ }^{2,3} \text {, A. Albinet }{ }^{1 *}
$$

${ }^{1}$ INERIS, Parc Technologique Alata, BP 2, 60550 Verneuil-en-Halatte, France

${ }^{2}$ CNRS, EPOC, UMR 5805 CNRS, 33405 Talence, France

${ }^{3}$ Université de Bordeaux, EPOC, UMR 5805 CNRS, 33405 Talence, France

${ }^{4}$ LSCE - UMR8212, CNRS-CEA-UVSQ, Gif-sur-Yvette, France

${ }^{5}$ University of Florence, Dipartimento di Fisica Astronomia, 50019, Sesto Fiorentino, Italy

${ }^{6}$ Institut Pierre Simon Laplace, CNRS, Ecole Polytechnique,91128 Palaiseau, France

*Correspondence to: alexandre.albinet@gmail.com; alexandre.albinet@ineris.fr;

deepchandra.srivastava@gmail.com

Phone - +33 34455 6485; 6949

Submitted for publication in Science of The Total Environment 


\begin{abstract}
The present study aimed at performing $\mathrm{PM}_{10}$ source apportionment, using positive matrix factorization (PMF), based on filter samples collected every $4 \mathrm{~h}$ at a sub-urban station in the Paris region (France) during a PM pollution event in March $2015\left(\mathrm{PM}_{10}>50 \mu \mathrm{g} \mathrm{m}^{-3}\right.$ for several consecutive days). The PMF model allowed to deconvolve 11 source factors. The use of specific primary and secondary organic molecular markers favoured the determination of common sources such as biomass burning and primary traffic emissions, as well as 2 specific biogenic SOA (marine + isoprene) and 3 anthropogenic SOA (nitro-PAHs + oxy-PAHs + phenolic compounds oxidation) factors. This study is probably the first one to report the use of methylnitrocatechol isomers as well as 1-nitropyrene to apportion secondary OA linked to biomass burning emissions and primary traffic emissions, respectively. Secondary organic carbon (SOC) fractions were found to account for $47 \%$ of the total OC. The use of organic molecular markers allowed the identification of $41 \%$ of the total SOC composed of anthropogenic SOA (namely, oxy-PAHs, nitro-PAHs and phenolic compounds oxidation, representing $15 \%, 9 \%, 11 \%$ of the total OC, respectively) and biogenic SOA (marine + isoprene) $(6 \%$ in total). Results obtained also showed that $35 \%$ of the total SOC originated from anthropogenic sources and especially PAH SOA (oxy-PAHs + nitro-PAHs), accounting for $24 \%$ of the total SOC, highlighting its significant contribution in urban influenced environments. Anthropogenic SOA related to nitro-PAHs and phenolic compounds exhibited a clear diurnal pattern with high concentrations during the night indicating the prominent role of night-time chemistry but with different chemical processes involved.
\end{abstract}

Keywords: Aerosol, Source apportionment, PMF, SOA, Molecular markers. 


\section{Introduction}

Atmospheric particulate matter (PM) plays an important role on climate and air quality (Boucher et al., 2013; Heal et al., 2012). To design effective PM concentration reduction strategies, their sources and contributions from each source need to be known thoroughly. Thus, several source apportionment methods have been developed for this purpose. Receptor-oriented modelling is one of the approaches that has been extensively used for PM source apportionment studies in the past decades (Belis et al., 2015; Hopke, 2016). The most commonly used receptor models include chemical mass balance (CMB) (Chow and Watson, 2002; Watson et al., 2002), positive matrix factorization (PMF) (Paatero and Tapper, 1994), and UNMIX (Henry, 1997). PMF is a powerful multivariate method that can resolve the dominant positive factors without prior knowledge of sources (Hopke et al., 2006; Kim et al., 2003; Shrivastava et al., 2007; Zhang et al., 2009).

Typically, PMF uses trace elements, and organic and elemental carbon (OC/EC), as well as secondary ions and metals as the input data matrix to explore the "co-variances" between species (Kim and Hopke, 2004; Kim et al., 2003). The use of tracers with high source specificity in the PMF model can enhance the interpretation of the factors. For example, levoglucosan is often used to trace the biomass burning source (Simoneit, 2002). The use of organic molecular markers in the PMF has resulted in considerable progress in the understanding of the organic aerosol (OA) fraction (Jaeckels et al., 2007; Laing et al., 2015; Schembari et al., 2014; Shrivastava et al., 2007; Srimuruganandam and Shiva Nagendra, 2012; Waked et al., 2014; Wang et al., 2012; Zhang et al., 2009). However, these studies have often been based on 12 or $24 \mathrm{~h}$ sampling periods, making difficult to capture the information on "fast" chemical processes related to OA emissions and formation. The use of a higher time-resolution datasets (e.g. filter samplings every $6 \mathrm{~h}$ or less) may 
facilitate the understanding of the processes involved, for both primary and secondary sources, and the analysis of their diurnal cycles.

This paper is the second paper of a two-part series demonstrating that the speciation of the OA fraction is important for PM source apportionment. Note that, the use of organic molecular markers in source apportionment studies is based on the assumption that these compounds are chemically stable in the atmosphere (i.e. tracer compounds) (Schauer et al., 1996). Some molecules can undergo a decay in the atmosphere by photochemical processes involving sunlight and atmospheric oxidants and their use may cause a bias in the source apportionment. Nevertheless, the first paper (Srivastava et al., 2018) highlighted the advantage of using primary and secondary organic molecular markers to resolve sources rarely apportioned in the literature such as two types of primary biogenic organic aerosols (fungal spores and plant debris), as well as specific biogenic and anthropogenic secondary OA (SOA). This second paper focuses on the identification of sources during a major PM pollution event using high resolution filter data in order to apportion specific primary (POA) and secondary OA fractions using various and distinctive markers and to understand the atmospheric chemical processes involved.

\section{Experimental}

\subsection{Monitoring site and sampling period}

Measurements were conducted at the ACTRIS SIRTA atmospheric supersite (Site Instrumental de Recherche par Télédétection Atmosphérique, 2.15 E; 48.71 N; 150 ma.s.l; http://sirta.ipsl.fr; Haeffelin et al. (2005)). This site is located approximately $25 \mathrm{~km}$ southwest from Paris city centre (Figure S1), surrounded by forests, agricultural fields and small villages, and is representative of suburban background conditions of the Paris region (Crippa et al., 2013a; Petit et al., 2017a; Petit 
et al., 2014; Sciare et al., 2011). An intensive campaign was performed from 6-21, March 2015. The late winter-early spring period was chosen on purpose as intense PM pollution events are usually observed in Northern France (and Europe) during this period of the year due to the combination of significant residential emissions, manure spreading, stagnant atmospheric conditions favouring the accumulation of pollutants and possible photochemical processes enhancing the formation of secondary aerosols (Bressi et al., 2013; Crippa et al., 2013a; Dupont et al., 2016; Favez et al., 2012; Fröhlich et al., 2015; Petit et al., 2017a; Petit et al., 2014; Sciare et al., 2011; Waked et al., 2014).

\subsection{Sample collection and co-located measurements}

$\mathrm{PM}_{10}$ samples (Tissu-quartz fibre filter, Pallflex, $\varnothing=150 \mathrm{~mm}$ ) were collected every $4 \mathrm{~h}$ from 621, March 2015 using a high-volume sampler (DA-80, Digitel; $30 \mathrm{~m}^{3} \mathrm{~h}^{-1}$ ). Prior to sampling, quartz fibre filters were pre-heated at $500{ }^{\circ} \mathrm{C}$ for $12 \mathrm{~h}$. After collection, samples were wrapped in aluminium foils, sealed in polyethylene bags, and stored at $-20{ }^{\circ} \mathrm{C}$ until analysis. Shipping of the samples to the different laboratories for analyses have been done by express post using cool boxes $\left(<5^{\circ} \mathrm{C}\right)$. A total of 92 samples and 5 field blanks were collected and analysed for an extended chemical characterization following the protocols described in section 2.3.

$\mathrm{PM}_{10}$, Black Carbon (BC), $\mathrm{NO}_{\mathrm{x}}$ and $\mathrm{O}_{3}$ concentrations were measured using co-located online analysers: TEOM-FDMS (1405F model, Thermo), multi-wavelength aethalometer (AE33 model, Magee Scientific), T200UP and T400 monitors (Teledyne API), respectively. Moreover, assuming that biomass burning and fossil fuel combustion were the two predominant combustion sources, $\mathrm{BC}$ from wood burning $\left(\mathrm{BC}_{\mathrm{wb}}\right)$ and fossil fuel $\left(\mathrm{BC}_{\mathrm{ff}}\right)$ emissions were estimated using the so-called “aethalometer model” (Drinovec et al., 2015; Sandradewi et al., 2008). The AE33 instrument uses 
a dual-spot technology which provides the automatic compensation (k) of the aerosol loading effect (Drinovec et al., 2015) over the 7 wavelengths of measurements of BC (from near UV to near IR). An inaccurate automatic compensation has been observed for several days due to high scattering during the pollution episode linked to high ammonium nitrate concentrations. The associated data were thus manually corrected with fixed k values as explained by Petit et al. (2017a) to improve the separation between $\mathrm{BC}_{\mathrm{wb}}$ and $\mathrm{BC}_{\mathrm{ff}}$. Finally, meteorological parameters such as temperature, relative humidity $(\mathrm{RH})$, wind direction, and wind speed were obtained from nearby weather station (about $5 \mathrm{~km}$ ).

\subsection{Analytical procedure}

A total number of 71 different chemical species have been quantified on filter samples. Major ions $\left(\mathrm{Cl}^{-}, \mathrm{NO}_{3}{ }^{-}, \mathrm{SO}_{4}{ }^{2-}, \mathrm{NH}_{4}^{+}, \mathrm{Ca}^{2+}, \mathrm{Na}^{+}, \mathrm{Mg}^{2+}, \mathrm{K}^{+}\right)$, methanesulfonic acid (MSA) and oxalate $\left(\mathrm{C}_{2} \mathrm{O}_{4}{ }^{2-}\right)$ were analysed using ion chromatography(Guinot et al., 2007). EC/OC was measured using a Sunset lab analyser and the EUSAAR-2 thermal protocol (Cavalli et al., 2010). Seven metal elements (namely $\mathrm{Ca}, \mathrm{Ti}, \mathrm{Mn}, \mathrm{Fe}, \mathrm{Ni}, \mathrm{Cu}$, and $\mathrm{Pb}$ ) were quantified by PIXE (particle-induced Xray emission) (Lucarelli et al., 2017; Lucarelli et al., 2011). Sugars, including known biomass burning markers (levoglucosan, mannosan and galactosan) and 3 polyols (arabitol, sorbitol and mannitol), were quantified using LC-PAD (Verlhac et al., 2013; Yttri et al., 2015). Nine PAHs, 14 oxy-PAHs, and 8 nitro-PAHs were quantified by UPLC/UV-Fluorescence and GC/NICI-MS (Albinet et al., 2006; Albinet et al., 2014; Albinet et al., 2013; Tomaz et al., 2016) using QuEChERS-like (Quick Easy Cheap Effective Rugged and Safe) extraction procedure (Albinet et al., 2014; Albinet et al., 2013). Slight modifications have been made in the purification step and the GC column used for oxy- and nitro-PAHs analysis allowing notably the clear separation of 2- 
and 3-nitrofluoranthenes. Thirteen SOA markers (notably including $\alpha$-methylglyceric acid, pinic acid, and methylnitrocatechols) (Nozière et al., 2015) were analysed by GC/EI-MS using authentic standards (Srivastava et al., 2018). Details of the analytical procedures and sample preparation for the analysis of PAHs and their derivatives, and SOA markers are provided in the Supplementary material (SM) (TablesS1to S4).

\subsection{Source apportionment methodology}

\subsubsection{Receptor modelling: PMF}

The U.S. Environmental Protection Agency (US-EPA) PMF 5.0 software has been used to perform $\mathrm{PM}_{10}$ source apportionment. PMF is based on a weighted least squares fit, where the weights are derived from the analytical uncertainty and provides the optimal solution by minimizing the residuals. Detailed information on this receptor modelling can be found elsewhere (Paatero, 1997; Paatero and Tapper, 1994) and in the SM, and also in the companion paper together

with uncertainty calculation details (Srivastava et al., 2018). $\mathrm{PM}_{10}$ concentrations were included as the total variable with low weight (weak variable) in the model to determine the source contributions.

\subsubsection{Criteria for the selection of species}

The choice of the species used as input data for the PMF analysis is a crucial step, which can significantly influence the model results (Lim et al., 2010). Usually, the selection of the species is based on the signal-to-noise ratio (S/N) (Paatero and Hopke, 2003). Here, only species with a S/N ratio above 0.2 were considered (Table S5). In addition, the following set of criteria were used for the final selection of the input species: major PM chemical species, compounds with at least $40 \%$ 
of total data points above the detection limit, and those being considered as specific markers of a given source (e.g., $\alpha$-methylglyceric ( $\alpha$-MGA) and 2-methylerythritol acid (2-MT) (SOA markers of isoprene oxidation), 2,3-dihydroxy-4-oxopentanoic acid (DHOPA) (SOA marker of toluene oxidation), methylnitrocatechol isomers (SOA from phenolic compound oxidation mainly emitted by biomass burning)) (Carlton et al., 2009; Iinuma et al., 2010; Kleindienst et al., 2004) (Table S6).

Furthermore, when several specific markers of a given source were available, criteria previously described by Srivastava et al. (2018), such as the selection of only one or two representative species per expected source and the selection of markers mainly present in the particulate phase, have been applied.

Finally, a total number of 34chemical species (listed in Table S6) were used in the present PM 10 source apportionment study.

\subsubsection{Optimization of the final solution}

Optimization of the final solution was based on the application of constraints to obtained clear factor chemical profiles. The general framework for applying constraints to PMF solutions has already been discussed elsewhere (Amato and Hopke, 2012; Amato et al., 2009). A priori information is introduced into the model as auxiliary terms in the object function (Q) (see the SM for details) by the implementation of so-called "pulling" (Paatero and Hopke, 2009). "Soft pulling" (species pulled up maximally and/or pulled down maximally)" and "hard pulling" (with defined limits) type of constraints were applied, where species in the factors were selectively pulled down or up. Details related to the constraints applied to each factor profile are given in Table S7.

The change in the $\mathrm{Q}$ values, were considered here as a diagnostic parameter to provide insight into the rotation of factors. All model runs were carefully monitored by examining the Q values 
obtained in the robust mode. The observed change in the Q-robust was approximately 5\% (Norris et al., 2014).

Three criteria, including correlation coefficient (r) between the measured and modelled species, bootstrap, and t-test (two-tailed paired t-test) performed on the base and constraint runs, were used to select the optimal solution, as explained previously (Srivastava et al., 2018).

A threshold of $80 \%$ for the bootstrap was considered to indicate that the chosen solution may be appropriate. The species showing poor correlations $(r<0.5)$ between observed and modelled concentrations were carefully examined to determine whether the species should be downweighted or excluded. Student's t-test was used to evaluate the effectiveness of the applied constraints and to verify if the differences were statistically insignificant for all source profiles (two-tailed paired t-test significance test at $\mathrm{p}<0.05$ probability).

The comparison between the reconstructed and measured input species showed very good agreement except for 2-methylerythritol $(\mathrm{r}<0.50, \mathrm{n}=92, \mathrm{p}<0.05)$ (Table S8). Bootstrapping on the final solution showed stable results with $\geq 85$ out of 100 bootstrap mapped factors (Table S9). No significant difference ( $\mathrm{p}$ values in the range $0.07-0.40$ ) was observed in the source chemical profiles between the base and the constrained runs (Table S10, Figures S2 and S3).

\subsection{Back trajectories and geographical origins}

A study of the geographical origin of selected identified sources has been performed by concentration-weighted trajectory (CWT). Such approach combines concentration data measured at the receptor site (in this case for each PM source) with back trajectories and helps to localize the air parcel responsible for high observed concentrations. For this purpose, back trajectories were calculated every $3 \mathrm{~h}$ using the standalone version of HYSPLIT v4.1 (Draxler, 1999; Stein et al., 
2015) and CWT calculations, and cluster analysis, were performed using the ZeFir Igor package (Petit et al., 2017b). Details about all these calculations have been reported previously (Petit et al., 2017a).

\section{Results and discussion}

\subsection{Overview of the $\mathbf{P M}_{10}$ chemical composition}

The daily $\mathrm{PM}_{10}$ mass concentrations ranged from $12-130 \mu \mathrm{g} \mathrm{m}^{-3}$, with an average of $49 \mu \mathrm{g} \mathrm{m}^{-3}$ during the campaign. The PM chemical composition showed a large predominance of secondary inorganic species, especially ammonium nitrate, highlighting the significance of secondary processes throughout the studied period (Petit et al., 2017a). OM concentrations ranged from 2 to $25 \mu \mathrm{g} \mathrm{m}^{-3}$, with an average value of about $12 \mu \mathrm{g} \mathrm{m}^{-3}$ (Figure 1). Note that the slight differences observed between the measured and the reconstructed $\mathrm{PM}_{10}$ mass concentrations may be due to the PM water content and/or some sampling artefacts together with the measurement uncertainties (Schwab et al., 2006). The measurement period can be divided into 3 sub-periods according to the air mass origins. The $\mathrm{SO}_{4} / \mathrm{EC}$ ratio was considered as a proxy to distinguish local from regional influences (Petit et al., 2015). This ratio showed a minimum value of about 2 during the period from $03 / 06$ to $03 / 11$, emphasizing the role of local emissions such as residential wood burning at the beginning of the studied period. This was notably supported by the high values of the levoglucosan/PM 10 ratio observed during this period together with low wind speeds (recirculation) (Figure S4). Nitrate concentrations started to slightly increase from $03 / 11$ and then the increase was more pronounced from $03 / 13$ together with the rise of the $\mathrm{SO}_{4} / \mathrm{EC}$ ratio, and associated with higher wind speeds coming from the NE direction, suggesting an influence of medium range transport. A substantial change was noticed in the PM composition during the most intense part of 
the campaign (03/18-03/21). The air masses originated mostly from the NNE direction with relatively high wind speeds, and high $\mathrm{SO}_{4} / \mathrm{EC}$ ratio (of about 8), indicating the advection of aged aerosols over the Paris region and highly impacted by long-range transport. In addition, the high concentration of oxalate (up to $0.5 \mu \mathrm{g} \mathrm{m}{ }^{-3}$ ) observed during this $3^{\text {rd }}$ period (Figure S5) suggests the significant role of photochemical processes enhancing the formation of more oxidized products.

\subsection{Description of PMF factors}

Based on the methodology described before (section 2.4), a 11-factor solution provided the most reasonable PMF result. The use of specific molecular organic markers in the PMF model allowed to deconvolve common aerosol sources such as primary traffic emissions, biomass burning, dust, mixed secondary aerosols, nitrate-rich factor, and sea salt, as well as 2 specific biogenic- and 3 anthropogenic-SOA sources. The sum of all these apportioned PMF factors (reconstructed $\mathrm{PM}_{10}$ ) showed a very good agreement with the measured $\mathrm{PM}_{10}$ concentrations $(r=0.97, \mathrm{n}=92, \mathrm{p}<0.05)$ (Figure 2 and Table S8). Identified aerosol sources, their chemical profiles and temporal evolutions are shown on Figures 3 and 4 and discussed individually hereafter.

\subsubsection{Mixed secondary aerosols}

This factor was obtained as the predominant one, with an average concentration of $18.2 \mu \mathrm{g} \mathrm{m}^{-3}$ and accounting for approximately $37 \%$ of the $\mathrm{PM}_{10}$ mass (Figure 2). It was characterized by high contributions of $\mathrm{NO}_{3}{ }^{-}, \mathrm{SO}_{4}{ }^{2-}$ and $\mathrm{NH}_{4}{ }^{+}(43 \%, 67 \%$ and $56 \%$ of the total mass, respectively) and showed a well-marked temporal variation, with very high concentrations during the second half of the campaign after 03/14 (Figure 3). In addition, this factor showed significant contributions of oxalate (36\% of the species within this factor), $\alpha$-MGA (25\%) and DHOPA (20\%), known to be 
typical secondary organic species or to be markers of SOA formation from the oxidation of isoprene and toluene (Carlton et al., 2009; Kawamura and Ikushima, 1993; Kleindienst et al., 2012).

Such a high contribution of this secondary factor is expected to be related to the aging of air masses during long range transport. This was also confirmed by the high $\mathrm{SO}_{4} / \mathrm{EC}$ ratio $(=50)$ observed in the factor chemical profile. As detailed in Petit et al. (2017a), a dense cloud cover was observed over Northern France during this period, with a limited amount of sunshine, and relatively high wind speeds (Figure 1) favouring the convective potential of lower atmospheric layer formation and advection of aged aerosol over the Paris region. This is furthermore supported by the CWT analysis showing low contribution of local/regional sources (Figure S6), which is consistent with the advected pattern of sulfate in Western Europe. This is also seconded by the findings published previously for the same period using on-line instrumentation (aerosol chemical speciation monitor, ACSM) (Petit et al., 2017a).

\subsubsection{Nitrate-rich factor}

This factor was characterized by the large proportions of $\mathrm{NO}_{3}{ }^{-}$and $\mathrm{NH}_{4}{ }^{+}(51$ and $40 \%$ of the total mass of each compound in this factor) (Figure 3). This source represents nitrate-rich aerosols due to the dominant fraction of ammonium nitrate and accounted for $23 \%$ of the total $\mathrm{PM}_{10}$ mass $\left(11.2 \mu \mathrm{g} \mathrm{m}^{-3}\right)$ (Figure 2). This factor also included small contributions of species such as oxalate (5\%) and 2-NF (15\%), known to be secondarily formed from the oxidation of PAH (fluoranthene) (Arey et al., 1986; Atkinson et al., 1987), and also benzo[a]fluorenone (B[a]Fone) (9\%), species probably of secondary origin during the studied period (see section 3.2.9).

High contributions of this factor at low wind speeds were observed (Figures 1 and 3), indicating the significant role of rather local formation of ammonium nitrate during this period. This was 
further supported by the CWT analysis (Figure S6), and also confirmed by the previous observations at the same site for the same PM pollution event as specified above (Petit et al., 2017a).

\subsubsection{Primary traffic emissions}

Given the constraints applied, this factor showed a significant amount of EC (35\% of species in this factor) along with relatively high content of metal elements such as $\mathrm{Fe}(82 \%), \mathrm{Cu}(53 \%)$, and Mn (28\%) (Figure 3). These species are typically associated with road transport in (peri-) urban environments. $\mathrm{Fe}, \mathrm{Cu}$, and $\mathrm{Mn}$ may originate from brake and tire abrasion and/or road dust resuspension (Garg et al., 2000; Hildemann et al., 1991; Pant and Harrison, 2012; Srivastava et al., 2016; Sternbeck et al., 2002), notifying the influence of both, exhaust and non-exhaust traffic emissions in this factor. This source attribution is furthermore supported by significant correlations with $\mathrm{BC}_{\mathrm{ff}}(\mathrm{r}=0.5, \mathrm{n}=92, \mathrm{p}<0.05)$ and $\mathrm{NO}_{\mathrm{x}}(\mathrm{r}=0.73, \mathrm{n}=70, \mathrm{p}<0.05)$ (Figure $\left.\mathrm{S} 7\right)$.

This factor accounted for $5 \%$ of the $\mathrm{PM}_{10}$ mass during the studied period, corresponding to an average concentration of $2.2 \mu \mathrm{g} \mathrm{m}^{-3}$ (Figure 2). This value is in good agreement with the previous observations made in the Paris region (average concentrations of about $2.3 \mu \mathrm{g} \mathrm{m}^{-3}$ in spring season according to Bressi et al. (2014).

Interestingly, the highest fraction of 1-nitropyrene (1-NP) (53\%), likely to be a good marker of diesel emissions (Keyte et al., 2016; Schulte et al., 2015; Zielinska et al., 2004a; Zielinska et al., 2004b), was associated with this factor. Irrespective of the constraint applied on 1-NP, it always showed maximum attribution with this factor along with species mentioned above. In addition, 1NP showed a good correlation with $\mathrm{NO}_{\mathrm{x}}(\mathrm{r}=0.71, \mathrm{n}=70, \mathrm{p}<0.05)$ (Figure $\left.\mathrm{S} 7\right)$. The traffic vehicle

fleet in France was composed of about $61.5 \%$ of diesel engines in 2015 and up to $80 \%$, taking into 
account all vehicle categories (including heavy trucks) (CCFA, 2016). These results showed that 1-NP can be used as a good primary organic molecular marker to trace traffic (diesel) exhaust emissions. To the best of our knowledge, this is the first report of the use of 1-NP to resolve the sources of primary traffic emissions in PMF model.

\subsubsection{Dust}

This factor was found as one of the major $\mathrm{PM}_{10}$ contributor, with an average concentration of $8.7 \mu \mathrm{g} \mathrm{m}^{-3}$ and accounting for $18 \%$ of the $\mathrm{PM}_{10}$ mass (Figure 2). It was notably composed of metals and cations, such as Ti, $\mathrm{Ca}^{2+}, \mathrm{Mg}^{2+}, \mathrm{Cu}, \mathrm{Mn}$ and $\mathrm{Fe}(68 \%, 75 \%, 28 \%, 31 \%, 39 \%$ and $18 \%$ of species in this factor respectively), together with a significant amount of OC (20\%) (Figure 3). Therefore, this source was identified as dust, including the influence of construction work, soil abrasion and resuspension (Amato et al., 2016a; Amato et al., 2016b; Andersen et al., 2007; Mossetti et al., 2005; Querol et al., 2004; Yin et al., 2005). High concentrations observed during the entire campaign corresponded to the air masses originated from the NE to $\mathrm{N}$ directions (Figure 1). Back trajectories analysis showed negligible impact from Sahara during this period (Figure S8).

\subsubsection{Sea salt}

This factor was characterized by high contributions of $\mathrm{Na}^{+}(76 \%), \mathrm{Mg}^{2+}(54 \%)$ and $\mathrm{Cl}^{-}(58 \%)$ (Figure 3). $\mathrm{Cl}^{-} / \mathrm{Na}^{+}$and $\mathrm{Mg}^{2+} / \mathrm{Na}^{+}$ratios of 1.0 and 0.1 , respectively, were on the same order of magnitude as the standard sea water composition (1.2 and 0.1, respectively) (Tang et al., 1997), and also similar to the values reported for the Paris region in previous study $\left(\mathrm{Cl}^{-} / \mathrm{Na}^{+}=0.96\right.$; $\mathrm{Mg}^{2+} / \mathrm{Na}^{+}=0.13$ ) (Bressi et al., 2014). The lower proportion of chloride can be explained by the occurrence of acid-base reactions between sea-salt particles and sulfuric and/or nitric acids, leading 
to the volatilization of $\mathrm{HCl}$ (Seinfeld and Pandis, 2012) during the transport of air masses from marine regions to the Paris area.

This source accounted for $2 \%$ of the total $\mathrm{PM}_{10}$ mass $\left(1.8 \mu \mathrm{g} \mathrm{m}^{-3}\right.$ ) (Figure 2) and showed its highest concentrations during the period from 03/10-03/12 when the origin of air masses changed from recirculation to the NE (Figures 1 and 3). The results from the CWT analysis highlighted the geographical origin of this source from the Atlantic Ocean and to a lesser extent from the North Sea (Figure S6).

\subsubsection{Biomass burning}

This factor was characterized by typical molecular markers from cellulose combustion with significant amounts of levoglucosan (levo, 44\%) and mannosan (manno, 38\%) (Simoneit, 2002; Simoneit, 1999) (Figure 3). It also included significant contributions of PAHs (B[a]F, B [ghi]P, and $\operatorname{In}[1,2,3-c d] P)(21-29 \%)$ and $\mathrm{K}^{+}(18 \%)$. Biomass burning concentrations were especially high at the beginning of the PM pollution event (Figure 3). This source accounted for $8 \%$ of the $\mathrm{PM}_{10}$ mass, with an average concentration of $3.8 \mu \mathrm{g} \mathrm{m} \mathrm{m}^{-3}$ (Figure 2). This factor also showed a good correlation with $\mathrm{BC}_{\mathrm{wb}}(\mathrm{r}=0.63, \mathrm{n}=92, \mathrm{p}<0.05)$ (Figure $\left.\mathrm{S} 9\right)$ even if the $\mathrm{BC}_{\mathrm{wb}} / \mathrm{BC}_{\mathrm{ff}}$ separation was probably not optimal during the last period of the campaign due to high loading of inorganic aerosols (Petit et al., 2017a).

This factor also included small contributions of known secondary organic species such as oxalate (17\%) and DHOPA (13\%), and also of benzo[a]fluorenone (B[a]Fone) (11\%), benzo[b]fluorenone (B[b]Fone) (12\%) and 9-nitroanthracene (9-NA) (19\%), species mainly of secondary origin during this specific event (see sections 3.2.9 and 3.2.10). Thus, this factor may contain a part of oxidized primary organic aerosol (OPOA), arising from the oxidation of organic 
compounds between the emission point and their introduction in ambient air (Nalin et al., 2016), but not resolved by the model

\subsubsection{Biogenic SOA-1 (marine)}

This factor contained $100 \%$ of methanesulfonic acid (MSA), a known secondary oxidation product of dimethylsulfide (DMS), which is emitted by phytoplankton and several types of anaerobe bacteria and released from the ocean into the atmosphere (Carlton et al., 2016; Charlson et al., 1987; Chasteen and Bentley, 2004; Crippa et al., 2013b).

The presence of DMS in seawater has been seen to covary with biological productivity and incident solar radiation at the Earth's surface (Andreae and Raemdonck, 1983; Bates et al., 1987). The CWT analysis showed a geographical origin of this factor from the North Sea (Figure S6). The worldwide distribution of chlorophyll, used as a phytoplankton indicator, estimated using satellitebased measurements, showed a hot spot of phytoplankton bloom near the North Sea in March 2015 and further confirmed the identification and the geographical origin of this SOA source from marine emissions (Figure S10).

The presence of $\mathrm{SO}_{4}{ }^{2-}$ in this factor is also considered to be partly related to the oxidation of DMS, as the MSA/SO ${ }_{4}^{2-}$ ratio for this factor of 0.14 was similar to values previously reported in the literature for such source (e.g., about 0.08 in Bove et al. (2016)).

This factor accounted for $2 \%$ of the $\mathrm{PM}_{10}$ mass $\left(0.8 \mu \mathrm{g} \mathrm{m}^{-3}\right)$ (Figure 2$)$ and followed a clear temporal variation with higher contributions during the period from 03/17 to 03/21 (Figures 1 and 4). This was in agreement with long range transport and aging processes as highlighted by the high concentrations of $\mathrm{NO}_{3}{ }^{-}$and $\mathrm{SO}_{4}{ }^{2-}$ during the last days of the PM pollution event (Petit et al., 2017a). 


\subsubsection{Biogenic SOA-2 (isoprene)}

This factor was characterized by significant contributions of oxidation products of isoprene ( $\alpha$ MGA and 2-MT; 65 and 66\%, respectively) (Carlton et al., 2009) (Figure 4). As expected for the late winter and early spring seasons, biogenic SOA factor showed a very low contribution to the $\mathrm{PM}_{10}$ mass $(<1 \%)$ corresponding to a concentration of $0.4 \mu \mathrm{g} \mathrm{m}^{-3}$ (Figure 2).

\subsubsection{Anthropogenic SOA-1 (oxy-PAHs)}

The sources of anthropogenic SOA factor were resolved using oxy-PAHs (dibenzo[b,d]pyran6-one (6H-DPone) (84\%), benzo[a]fluorenone (53\%) and benzo[b]fluorenone (60\%) (Figure 4). Dibenzo[b,d]pyran-6-one, a product of phenanthrene photooxidation has been described as a good marker of PAH SOA formation (Lee and Lane, 2010; Perraudin et al., 2007; Tomaz et al., 2017) while benzo[a]fluorenone and benzo[b]fluorenone may originate from both primary and secondary processes (Albinet et al., 2007; Tomaz et al., 2017). Here, both compounds showed significant correlations $(\mathrm{r}=0.55-0.57, \mathrm{n}=92, \mathrm{p}<0.05)$ with dibenzo[b,d]pyran-6-one, indicating the probable secondary origin of these compounds during the PM pollution event (Figure S11). This factor also showed a relatively high amount (16\% of species in this factor) of DHOPA, which is known as a SOA marker from toluene oxidation (Kleindienst et al., 2012). Finally, significant contributions of

primary species such as PAHs (B[a]F, B[a]P, B[ghi]P, and In[1,2,3-cd]P) (23-41\%), levoglucosan (19\%), mannosan (22\%) and 1-NP (17\%) were also noticed. Thus, this factor seemed characteristic of PAH SOA from anthropogenic sources including combustion processes such as biomass burning and traffic. A similar factor was already resolved using oxy-PAHs in the companion paper (Srivastava et al., 2018). 
Overall, anthropogenic SOA source (oxy-PAHs) accounted for approximately $2 \%$ of the total $\mathrm{PM}_{10}$ mass with a concentration of $1.1 \mu \mathrm{g} \mathrm{m}^{-3}$ on an average (Figure 2). High concentrations (up to $8 \mu \mathrm{g} \mathrm{m}^{-3}$ ) were especially observed during the 03/13-03/18 period, when air masses originated from the NE direction (Figures 1 and 4).

\subsubsection{Anthropogenic SOA-2 (nitro-PAHs)}

This source was characterized by the high fraction of 2-nitrofluoranthene (2-NFlt) (78\%) (Figure 4). 2-NFlt is only secondarily formed from the gas phase reaction between fluoranthene and $\mathrm{NO}_{2}$ initiated by $\mathrm{OH}$ (day-time)/ $\mathrm{NO}_{3}$ (night-time) radicals (Arey et al., 1986; Atkinson et al., 1987). Therefore, this factor was identified as another PAH SOA source but with different chemical processes involved (see section 3.3.2). In addition, this factor also included a significant contribution of 9-NA (41\%) which may originated from both, primary and secondary sources (Albinet et al., 2007; Ringuet et al., 2012b), as both processes were dominant during the sampling campaign.

Overall, this source had a very low contribution to the $\mathrm{PM}_{10}$ mass $(0.6 \%)$, corresponding to a concentration of $0.3 \mu \mathrm{g} \mathrm{m}^{-3}$ (Figure 2). The discernible temporal pattern with higher concentrations during the night indicated the prominent role of night-time chemistry in the formation of nitroPAHs during this period (Figure 4) as previously observed at the same site (Ringuet et al., 2012a).

\subsubsection{Anthropogenic SOA-3 (phenolic oxidation)}

This factor was resolved using 4-methyl-5-nitrocatechol (4-Me5Nc) and 3-methyl-5nitrocatechol (3-Me5Nc) with very high contributions of both compounds (94-100\%) (Figure 4). These species are typical by-products of SOA formation from the photooxidation of cresols mainly 
originating from biomass burning emissions (Bruns et al., 2016; Iinuma et al., 2010). In addition, this factor also showed significant contributions of levoglucosan (19\%), mannosan (15\%), and DHOPA (13\%), mainly illustrating the characteristic of biomass burning SOA. To the best of our knowledge, this study is probably the first one reporting the use of methylnitrocatechol isomers for the apportionment, using PMF, of anthropogenic SOA linked to biomass burning.

The source showed a quite low contribution to the $\mathrm{PM}_{10}$ mass of $2 \%$ on an average corresponding to a concentration of $0.8 \mu \mathrm{g} \mathrm{m}^{-3}$ (Figure 2). However, high concentrations and contributions were observed during the recirculation period (up to $1.4 \mu \mathrm{g} \mathrm{m}^{-3}$ corresponding to $5 \%$ of PM) in agreement with the dominant period of biomass burning emissions.

\subsection{Focus on organic aerosols (OA)}

\subsubsection{OA sources and formation processes}

Assuming a OC-to-OA conversion factor around 1.8 (Sciare et al., 2011), OA represented about $25 \%$ of the total $\mathrm{PM}_{10}$ mass during the studied period. Major contributors were dust (representing $20 \%$ of total OC on average for the campaign), biomass burning (19\%), and mixed secondary aerosols $(17 \%)$, followed by primary traffic emissions (14\%) and nitrate-rich factor (11\%). Only sea salt did not show any contribution to OC mass (Figure S12). Primary OC (POC) was estimated as the sum of OC fractions associated with dust, biomass burning, and traffic, whereas OC present in the other factors (namely biogenic SOA-1 \& 2, anthropogenic SOA-1, $2 \& 3$, mixed secondary aerosols and nitrate-rich factor) was considered as representing secondary OC (SOC). These calculations led to almost equivalent contributions of POC and SOC to the total OC (53\% and 47\% on average for the campaign, respectively). 
As shown in Figure 5, the use of specific organic molecular markers allowed the clear identification of $41 \%$ of the total SOC composed of anthropogenic SOA (oxy-PAHs, nitro-PAHs, phenolic oxidation, corresponding to average OC contributions of $15 \%, 9 \%, 11 \%$, respectively) and biogenic SOA (marine + isoprene, $6 \%$ in total). The low contributions of these last two sources may be related to the low biogenic activity during the sampling period (end of winter, beginning of spring). Anthropogenic SOAs were thus considered as the dominant SOC contributors identified and in particular PAH SOA, accounting for $24 \%$ of the total SOC. This results highlights the significant contribution of anthropogenic SOA in urban influenced environments, in good agreement with the literature (Shakya and Griffin, 2010; Srivastava et al., 2018; Zhang and Ying, 2012).

Secondary processes leading to the presence of OA within the nitrate-rich factor and mixed secondary aerosols remained unknown. However, previous studies already suggested that OC fractions associated to nitrate- and/or sulfate-rich factors can be considered as secondary (Ke et al., 2008; Lee et al., 2008; Pekney et al., 2006). This was confirmed here by the presence of oxalate, $\alpha$-MGA, 2-NFlt and DHOPA in both factors. Formation processes leading to OA directly associated with secondary inorganic aerosols may notably include condensation of semi-volatile organic compounds onto the surface of pre-existing particles (Amato et al., 2009; Favez et al., 2007; Surratt et al., 2007), and nucleation mechanisms from various gaseous precursors such as mono- and polyaromatic compounds, alkanes, alkenes...(Lim and Ziemann, 2005; Tkacik et al., 2012; Zhao et al., 2014), as well as the formation of organosulfates and/or organonitrates (Riva et al., 2015; Surratt et al., 2006). Further works are still needed to identify and quantify relevant and specific molecular markers that could help to evaluate the significance of these processes using source-receptor models such as PMF. 


\subsubsection{Diurnal profiles}

Figure 6 shows the diurnal profiles of significant and relevant OA factors obtained within the present study. The biomass burning factor showed a pronounced peak at night-time, which is consistent with human activities. As expected too, traffic exhibited two pronounced peaks corresponding to morning and evening commuting periods.

It is known that oxy-PAH secondary formation involves photochemical reactions of parent PAHs with ozone or OH radicals (Vione et al., 2004; Walgraeve et al., 2010). However, no specific trend was observed for anthropogenic SOA-1 during the studied period.

Both other anthropogenic SOA factors (nitro-PAHs and phenolic oxidation) exhibited a clear diurnal pattern with high concentrations at night with peaks at distinct times suggesting a significant role of night-time chemistry but with different chemical processes involved. For anthropogenic SOA-2 (nitro-PAHs), an increase of the concentrations from early night until early morning was observed. These diurnal profiles agreed with the ones usually reported for nitrate radical (Reisen and Arey, 2005), indicating the predominance of such processes in the secondary formation of nitro-PAHs. The peaks of concentrations for anthropogenic SOA-3 (phenolic oxidation) were observed in early night in coherence with the biomass burning emissions as the main source of phenolic SOA precursor compounds.

For both anthropogenic SOA-2 and-3, high RH conditions observed during the night (Figure S13) could also favour secondary formation processes (Jia and Xu, 2014). However, the aerosol liquid water content, together with the higher solubility of the phenolic precursor compounds as well as methylnitrocatechols, could explain the low concentrations of anthropogenic SOA-3 observed during the second part of the night until the morning. Nitro-PAHs are less water soluble 
than methylnitrocatechols and consequently, they may tend to partition into the solid phase instead of the aqueous one, explaining the differences observed in the diurnal profiles between both factors. Finally, the degradation of both category of compounds during the day-time under solar irradiation cannot be ruled out.

\section{Conclusion}

The use of specific primary and secondary molecular markers, with high time resolution data, in PMF model allowed to resolve 11 major $\mathrm{PM}_{10}$ sources during a PM pollution event observed in March 2015 in the Paris region. Besides common factors (biomass burning, traffic, dust, sea salt, secondary inorganic aerosols), 2 specific biogenic SOA (marine + isoprene) and 3 anthropogenic SOA (nitro-PAHs + oxy-PAHs + phenolic oxidation) factors have been identified. Results obtained showed that 1-NP can be used as a good primary organic molecular marker to trace traffic emissions and notably diesel exhaust ones.

A special attention was put on SOA, roughly accounting for half of the total OC loading. Molecular markers used in the present study allowed elucidating the probable precursor's origins of about $41 \%$ of the total SOC fraction. However, future studies are still needed to focus on the identification, and then the incorporation into PMF analysis, of molecular markers from other known SOA precursors (alkanes, alkenes, mono- and polyaromatic compounds) and of class of compounds which significantly contribute to the SOC fraction (i.e., organosulfates and organonitrates) to further discriminate the nature of $\mathrm{OA}$ associated with secondary inorganic sources.

The results obtained in this study highlighted that $35 \%$ of the total SOC originated from anthropogenic sources. In particular, PAH SOA (oxy-PAHs + nitro-PAHs) accounted for $24 \%$ of 
the total SOC, highlighting the significance of such SOA precursors in urban influenced environments.

Finally, high time-resolution filter dataset available for the present study allowed a better understanding of the chemical processes involved, notably based on the investigation of diurnal variations. Anthropogenic SOA related to nitro-PAHs and phenolic compounds exhibited a clear temporal pattern with high contributions during the night but with different chemical processes involved. The effects of relative humidity and liquid aerosol content in the formation of these secondary compounds are still not fully understood and should be investigated.

\section{Acknowledgements}

This work has notably been supported by the French Ministry of Environment (METL) and the national reference laboratory for air quality monitoring (LCSQA), as well as by the FP7 ACTRIS and H2020 ACTRIS projects. The authors gratefully acknowledge François Truong (LSCE) and Robin Aujay-Plouzeau (INERIS) for taking care of samples and instrumentation and other staff at the SIRTA observatory for providing weather-related data used in this study. They also thank François Kany and Serguei Stavrovski (INERIS) for sample preparation and PAH analyses and Patrick Bodu for the graphical abstract design.

\section{References}

Albinet, A., Leoz-Garziandia, E., Budzinski, H., Villenave, E., 2006. Simultaneous analysis of oxygenated and nitrated polycyclic aromatic hydrocarbons on standard reference material 
1649a (urban dust) and on natural ambient air samples by gas chromatography-mass spectrometry with negative ion chemical ionisation. J. Chromatogr. A. 1121, 106-113.

Albinet, A., Leoz-Garziandia, E., Budzinski, H., Villenave, E., 2007. Polycyclic aromatic hydrocarbons (PAHs), nitrated PAHs and oxygenated PAHs in ambient air of the Marseilles area (South of France): Concentrations and sources. Sci. Total Environ. 384, 280-292.

Albinet, A., Nalin, F., Tomaz, S., Beaumont, J., Lestremau, F., 2014. A simple QuEChERS-like extraction approach for molecular chemical characterization of organic aerosols: application to nitrated and oxygenated PAH derivatives (NPAH and OPAH) quantified by GC-NICIMS. Anal. Bioanal. Chem. 406, 3131-3148.

Albinet, A., Tomaz, S., Lestremau, F., 2013. A really quick easy cheap effective rugged and safe (QuEChERS) extraction procedure for the analysis of particle-bound PAHs in ambient air and emission samples. Sci. Total Environ. 450-451, 31-8.

Amato, F., Alastuey, A., Karanasiou, A., Lucarelli, F., Nava, S., Calzolai, G., Severi, M., Becagli, S., Gianelle, V. L., Colombi, C., Alves, C., Custódio, D., Nunes, T., Cerqueira, M., Pio, C., Eleftheriadis, K., Diapouli, E., Reche, C., Minguillón, M. C., Manousakas, M. I., Maggos, T., Vratolis, S., Harrison, R. M., Querol, X., 2016a. AIRUSE-LIFE+: a harmonized PM speciation and source apportionment in five southern European cities. Atmos. Chem. Phys. $16,3289-3309$.

Amato, F., Favez, O., Pandolfi, M., Alastuey, A., Querol, X., Moukhtar, S., Bruge, B., Verlhac, S., Orza, J. A. G., Bonnaire, N., Le Priol, T., Petit, J. F., Sciare, J., 2016b. Traffic induced particle resuspension in Paris: Emission factors and source contributions. Atmos. Environ. $129,114-124$. 
Amato, F., Hopke, P. K., 2012. Source apportionment of the ambient PM2.5 across St. Louis using constrained positive matrix factorization. Atmos. Environ. 46, 329-337.

Amato, F., Pandolfi, M., Escrig, A., Querol, X., Alastuey, A., Pey, J., Perez, N., Hopke, P. K., 2009. Quantifying road dust resuspension in urban environment by Multilinear Engine: A comparison with PMF2. Atmos. Environ. 43, 2770-2780.

Andersen, Z. J., Wahlin, P., Raaschou-Nielsen, O., Scheike, T., Loft, S., 2007. Ambient particle source apportionment and daily hospital admissions among children and elderly in Copenhagen. J. Expo. Sci. Environ. Epidemiol. 17, 625.

Andreae, M. O., Raemdonck, H., 1983. Dimethyl sulfide in the surface ocean and the marine atmosphere: a global view. Science. 221, 744-7.

Arey, J., Zielinska, B., Atkinson, R., Winer, A. M., Ramdahl, T., Pitts, J. N., 1986. The formation of nitro-PAH from the gas-phase reactions of fluoranthene and pyrene with the $\mathrm{OH}$ radical in the presence of NOx. Atmos. Environ. 20, 2339-2345.

Atkinson, R., Arey, J., Zielinska, B., Pitts, J. N., Winer, A. M., 1987. Evidence for the transformation of polycyclic organic matter in the atmosphere. Atmos. Environ. 21, 22612262.

Bates, T. S., Charlson, R. J., Gammon, R. H., 1987. Evidence for the climatic role of marine biogenic sulphur. Nature. 329, 319-321.

Belis, C. A., Karagulian, F., Amato, F., Almeida, M., Artaxo, P., Beddows, D. C. S., Bernardoni, V., Bove, M. C., Carbone, S., Cesari, D., Contini, D., Cuccia, E., Diapouli, E., Eleftheriadis, K., Favez, O., El Haddad, I., Harrison, R. M., Hellebust, S., Hovorka, J., Jang, E., Jorquera, 
H., Kammermeier, T., Karl, M., Lucarelli, F., Mooibroek, D., Nava, S., Nøjgaard, J. K., Paatero, P., Pandolfi, M., Perrone, M. G., Petit, J. E., Pietrodangelo, A., Pokorná, P., Prati, P., Prevot, A. S. H., Quass, U., Querol, X., Saraga, D., Sciare, J., Sfetsos, A., Valli, G., Vecchi, R., Vestenius, M., Yubero, E., Hopke, P. K., 2015. A new methodology to assess the performance and uncertainty of source apportionment models II: The results of two European intercomparison exercises. Atmos. Environ. 123, 240-250.

Boucher, O., Randall, D., Artaxo, P., Bretherton, C., Feingold, G., Forster, P., Kerminen, V.-M., Kondo, Y., Liao, H., Lohmann, U. Clouds and aerosols. Climate change 2013: the physical science basis. Contribution of Working Group I to the Fifth Assessment Report of the Intergovernmental Panel on Climate Change. Cambridge University Press, 2013, pp. 571657.

Bove, M. C., Brotto, P., Calzolai, G., Cassola, F., Cavalli, F., Fermo, P., Hjorth, J., Massabò, D., Nava, S., Piazzalunga, A., Schembari, C., Prati, P., 2016. PM10 source apportionment applying PMF and chemical tracer analysis to ship-borne measurements in the Western Mediterranean. Atmos. Environ. 125, 140-151.

Bressi, M., Sciare, J., Ghersi, V., Bonnaire, N., Nicolas, J. B., Petit, J. E., Moukhtar, S., Rosso, A., Mihalopoulos, N., Féron, A., 2013. A one-year comprehensive chemical characterisation of fine aerosol (PM2.5) at urban, suburban and rural background sites in the region of Paris (France). Atmos. Chem. Phys. 13, 7825-7844.

Bressi, M., Sciare, J., Ghersi, V., Mihalopoulos, N., Petit, J. E., Nicolas, J. B., Moukhtar, S., Rosso, A., Féron, A., Bonnaire, N., Poulakis, E., Theodosi, C., 2014. Sources and geographical origins of fine aerosols in Paris (France). Atmos. Chem. Phys. 14, 8813-8839. 
Bruns, E. A., El Haddad, I., Slowik, J. G., Kilic, D., Klein, F., Baltensperger, U., Prévôt, A. S. H., 2016. Identification of significant precursor gases of secondary organic aerosols from residential wood combustion. Sci. Rep. 6, 27881.

Carlton, A., Jimenez, J., Ambrose, J., Brown, S., Baker, K., Brock, C., Cohen, R., Edgerton, S., Farkas, C., Farmer, D., 2016. The Southeast Atmosphere Studies (SAS): Coordinated Investigation and Discovery to Answer Critical Questions About Fundamental Atmospheric Processes. Bull. Am. Meteorol. Soc.

Carlton, A. G., Wiedinmyer, C., Kroll, J. H., 2009. A review of Secondary Organic Aerosol (SOA) formation from isoprene. Atmos. Chem. Phys. 9, 4987-5005.

Cavalli, F., Viana, M., Yttri, K., Genberg, J., Putaud, J.-P., 2010. Toward a standardised thermaloptical protocol for measuring atmospheric organic and elemental carbon: the EUSAAR protocol. Atmos. Meas. Tech. 3, 79-89.

CCFA, 2016. The French Automotive Industry. Analysis and Statistics 2016. CCFA (Comité des Constructeurs Français d'Automobiles). http://temis.documentation.developpementdurable.gouv.fr/document.html?id=Temis-0000921

CEN, 2017. European Committee for Standardization, EN-16909: 2017 - Ambient Air measurements of elemental carbon (EC) and organic carbon (OC) deposited on filters. CEN, Brussels (Belgium)

Charlson, R. J., Lovelock, J. E., Andreae, M. O., Warren, S. G., 1987. Oceanic phytoplankton, atmospheric sulphur, cloud albedo and climate. Nature. 326, 655-661. 
Chasteen, T. G., Bentley, R., 2004. Volatile Organic Sulfur Compounds of Environmental Interest: Dimethyl Sulfide and Methanethiol. An Introductory Overview. J. Chem. Educ. 81, 1524.

Chow, J. C., Watson, J. G., 2002. Review of PM2.5 and PM10 Apportionment for Fossil Fuel Combustion and Other Sources by the Chemical Mass Balance Receptor Model. Energy Fuels. 16, 222-260.

Crippa, M., Canonaco, F., Slowik, J. G., El Haddad, I., DeCarlo, P. F., Mohr, C., Heringa, M. F., Chirico, R., Marchand, N., Temime-Roussel, B., Abidi, E., Poulain, L., Wiedensohler, A., Baltensperger, U., Prévôt, A. S. H., 2013a. Primary and secondary organic aerosol origin by combined gas-particle phase source apportionment. Atmos. Chem. Phys. 13, 8411-8426.

Crippa, M., El Haddad, I., Slowik, J. G., DeCarlo, P. F., Mohr, C., Heringa, M. F., Chirico, R., Marchand, N., Sciare, J., Baltensperger, U., Prévôt, A. S. H., 2013b. Identification of marine and continental aerosol sources in Paris using high resolution aerosol mass spectrometry. J. Geophys. Res.-Atmos. 118, 1950-1963.

Draxler, R., 1999. Hysplit4 User's Guide. NOAA Tech. Memo. ERL ARL-230, 35 pp. http://www.arl.noaa.gov/documents/reports/hysplit_user_guide.pdf.

Drinovec, L., Močnik, G., Zotter, P., Prévôt, A. S. H., Ruckstuhl, C., Coz, E., Rupakheti, M., Sciare, J., Müller, T., Wiedensohler, A., Hansen, A. D. A., 2015. The "dual-spot" Aethalometer: an improved measurement of aerosol black carbon with real-time loading compensation. Atmos. Meas. Tech. 8, 1965-1979.

Dupont, J., Haeffelin, M., Badosa, J., Elias, T., Favez, O., Petit, J., Meleux, F., Sciare, J., Crenn, V., Bonne, J. L., 2016. Role of the boundary layer dynamics effects on an extreme air pollution event in Paris. Atmos. Environ. 141, 571 - 579. 
Favez, O., Cachier, H., Sciare, J., Le Moullec, Y., 2007. Characterization and contribution to PM2.5 of semi-volatile aerosols in Paris (France). Atmos. Environ. 41, 7969-7976.

Favez, O., Petit, J.-E., Bessagnet, B., Meleux, F., Chiappini, L., Lemeur, S., Labartette, C., Chappaz, C., Guergnion, P.-Y., Saison, J.-Y., 2012. Caractéristiques et origines principales des épisodes de pollution hivernaux aux PM10 en France. Pollution Atmosphérique: climat, santé, société. 163-181.

Fröhlich, R., Crenn, V., Setyan, A., Belis, C. A., Canonaco, F., Favez, O., Riffault, V., Slowik, J. G., Aas, W., Aijälä, M., Alastuey, A., Artiñano, B., Bonnaire, N., Bozzetti, C., Bressi, M., Carbone, C., Coz, E., Croteau, P. L., Cubison, M. J., Esser-Gietl, J. K., Green, D. C., Gros, V., Heikkinen, L., Herrmann, H., Jayne, J. T., Lunder, C. R., Minguillón, M. C., Močnik, G., O'Dowd, C. D., Ovadnevaite, J., Petralia, E., Poulain, L., Priestman, M., Ripoll, A., Sarda-Estève, R., Wiedensohler, A., Baltensperger, U., Sciare, J., Prévôt, A. S. H., 2015. ACTRIS ACSM intercomparison - Part 2: Intercomparison of ME-2 organic source apportionment results from 15 individual, co-located aerosol mass spectrometers. Atmos. Meas. Tech. 8, 2555-2576.

Garg, B. D., Cadle, S. H., Mulawa, P. A., Groblicki, P. J., Laroo, C., Parr, G. A., 2000. Brake Wear Particulate Matter Emissions. Environ. Sci. Technol. 34, 4463-4469.

Guinot, B., Cachier, H., Sciare, J., Tong, Y., Xin, W., Jianhua, Y., 2007. Beijing aerosol: Atmospheric interactions and new trends. J. Geophys. Res.-Atmos. 112,

Haeffelin, M., Barthès, L., Bock, O., Boitel, C., Bony, S., Bouniol, D., Chepfer, H., Chiriaco, M., Cuesta, J., Delanoë, J., Drobinski, P., Dufresne, J. L., Flamant, C., Grall, M., Hodzic, A., Hourdin, F., Lapouge, F., Lemaître, Y., Mathieu, A., Morille, Y., Naud, C., Noël, V., 
O'Hirok, W., Pelon, J., Pietras, C., Protat, A., Romand, B., Scialom, G., Vautard, R., 2005. SIRTA, a ground-based atmospheric observatory for cloud and aerosol research. Ann. Geophys. 23, 253-275.

Heal, M. R., Kumar, P., Harrison, R. M., 2012. Particles, air quality, policy and health. Chem. Soc. Rev. 41, 6606-6630.

Henry, R. C., 1997. History and fundamentals of multivariate air quality receptor models. Chemom. Intell. Lab. Syst. 37, 37-42.

Hildemann, L. M., Markowski, G. R., Cass, G. R., 1991. Chemical composition of emissions from urban sources of fine organic aerosol. Environ. Sci. Technol. 25, 744-759.

Hopke, P. K., 2016. Review of receptor modeling methods for source apportionment. J Air Waste Manag Assoc. 66, 237-59.

Hopke, P. K., Ito, K., Mar, T., Christensen, W. F., Eatough, D. J., Henry, R. C., Kim, E., Laden, F., Lall, R., Larson, T. V., Liu, H., Neas, L., Pinto, J., Stolzel, M., Suh, H., Paatero, P., Thurston, G. D., 2006. PM source apportionment and health effects: 1. Intercomparison of source apportionment results. J. Expo. Sci. Environ. Epidemiol. 16, 275-86.

Iinuma, Y., Boge, O., Grafe, R., Herrmann, H., 2010. Methyl-nitrocatechols: atmospheric tracer compounds for biomass burning secondary organic aerosols. Environ. Sci. Technol. 44, $8453-9$.

Jaeckels, J. M., Bae, M.-S., Schauer, J. J., 2007. Positive matrix factorization (PMF) analysis of molecular marker measurements to quantify the sources of organic aerosols. Environ. Sci. Technol. 41, 5763-5769. 
Jia, L., Xu, Y., 2014. Effects of Relative Humidity on Ozone and Secondary Organic Aerosol Formation from the Photooxidation of Benzene and Ethylbenzene. Aerosol Sci. Technol. 48, 1-12.

Kawamura, K., Ikushima, K., 1993. Seasonal changes in the distribution of dicarboxylic acids in the urban atmosphere. Environ. Sci. Technol. 27, 2227-2235.

Ke, L., Liu, W., Wang, Y., Russell, A. G., Edgerton, E. S., Zheng, M., 2008. Comparison of PM2.5 source apportionment using positive matrix factorization and molecular marker-based chemical mass balance. Sci. Total Environ. 394, 290-302.

Keyte, I. J., Albinet, A., Harrison, R. M., 2016. On-road traffic emissions of polycyclic aromatic hydrocarbons and their oxy- and nitro- derivative compounds measured in road tunnel environments. Sci. Total Environ. 566-567, 1131-1142.

Kim, E., Hopke, P. K., 2004. Source Apportionment of Fine Particles in Washington, DC, Utilizing Temperature-Resolved Carbon Fractions. J. Air Waste Manage. Assoc. 54, 773-785.

Kim, E., Hopke, P. K., Edgerton, E. S., 2003. Source identification of atlanta aerosol by positive matrix factorization. J. Air Waste Manage. Assoc. 53, 731-9.

Kleindienst, T., Conver, T., McIver, C., Edney, E., 2004. Determination of secondary organic aerosol products from the photooxidation of toluene and their implications in ambient PM2. 5. J. Atmos. Chem. 47, 79-100.

Kleindienst, T. E., Jaoui, M., Lewandowski, M., Offenberg, J. H., Docherty, K. S., 2012. The formation of SOA and chemical tracer compounds from the photooxidation of naphthalene 
and its methyl analogs in the presence and absence of nitrogen oxides. Atmos. Chem. Phys. $12,8711-8726$.

Laing, J. R., Hopke, P. K., Hopke, E. F., Husain, L., Dutkiewicz, V. A., Paatero, J., Viisanen, Y., 2015. Positive Matrix Factorization of 47 Years of Particle Measurements in Finnish Arctic. Aerosol. Air Qual. Res. 15, 188-207

Lee, J., Lane, D. A., 2010. Formation of oxidized products from the reaction of gaseous phenanthrene with the $\mathrm{OH}$ radical in a reaction chamber. Atmos. Environ. 44, 2469-2477.

Lee, S., Liu, W., Wang, Y., Russell, A. G., Edgerton, E. S., 2008. Source apportionment of PM 2.5: Comparing PMF and CMB results for four ambient monitoring sites in the southeastern United States. Atmos. Environ. 42, 4126-4137.

Lim, J.-M., Lee, J.-H., Moon, J.-H., Chung, Y.-S., Kim, K.-H., 2010. Source apportionment of PM10 at a small industrial area using Positive Matrix Factorization. Atmos. Res. 95, 88100.

Lim, Y. B., Ziemann, P. J., 2005. Products and mechanism of secondary organic aerosol formation from reactions of n-alkanes with $\mathrm{OH}$ radicals in the presence of NOx. Environ. Sci. Technol. 39, 9229-36.

Lucarelli, F., Calzolai, G., Chiari, M., Nava, S., Carraresi, L., 2017. Study of atmospheric aerosols by IBA techniques: The LABEC experience. Nucl. Instrum. Methods Phys. Res., Sect. B.

Lucarelli, F., Nava, S., Calzolai, G., Chiari, M., Udisti, R., Marino, F., 2011. Is PIXE still a useful technique for the analysis of atmospheric aerosols? The LABEC experience. X-Ray Spectrom. 40, 162-167. 
Mossetti, S., Angius, S. P., Angelino, E., 2005. Assessing the impact of particulate matter sources in the Milan urban area. Int. J. Environ. Pollut. 24, 247-259.

Nalin, F., Golly, B., Besombes, J.-L., Pelletier, C., Aujay-Plouzeau, R., Verlhac, S., Dermigny, A., Fievet, A., Karoski, N., Dubois, P., Collet, S., Favez, O., Albinet, A., 2016. Fast oxidation processes from emission to ambient air introduction of aerosol emitted by residential log wood stoves. Atmos. Environ. 143, 15-26.

Norris, G., Duvall, R., Brown, S., Bai, S. EPA Positive Matrix Factorization (PMF) 5.0 fundamentals and User Guide Prepared for the US Environmental Protection Agency Office of Research and Development, Washington, DC. DC EPA/600/R-14/108, 2014.

Nozière, B., Kalberer, M., Claeys, M., Allan, J., D’Anna, B., Decesari, S., Finessi, E., Glasius, M., Grgić, I., Hamilton, J. F., Hoffmann, T., Iinuma, Y., Jaoui, M., Kahnt, A., Kampf, C. J., Kourtchev, I., Maenhaut, W., Marsden, N., Saarikoski, S., Schnelle-Kreis, J., Surratt, J. D., Szidat, S., Szmigielski, R., Wisthaler, A., 2015. The Molecular Identification of Organic Compounds in the Atmosphere: State of the Art and Challenges. Chem. Rev.

Paatero, P., 1997. Least squares formulation of robust non-negative factor analysis. Chemom. Intell. Lab. Syst. 37, 23-35.

Paatero, P., Hopke, P. K., 2003. Discarding or downweighting high-noise variables in factor analytic models. Anal. Chim. Acta. 490, 277-289.

Paatero, P., Hopke, P. K., 2009. Rotational tools for factor analytic models. J. Chemom. 23, 91100. 
Paatero, P., Tapper, U., 1994. Positive matrix factorization: A non-negative factor model with optimal utilization of error estimates of data values. Environmetrics. 5, 111-126.

Pant, P., Harrison, R. M., 2012. Critical review of receptor modelling for particulate matter: a case study of India. Atmos. Environ. 49, 1-12.

Pekney, N. J., Davidson, C. I., Robinson, A., Zhou, L., Hopke, P., Eatough, D., Rogge, W. F., 2006. Major Source Categories for PM2.5 in Pittsburgh using PMF and UNMIX. Aerosol Sci. Technol. 40, 910-924.

Perraudin, E., Budzinski, H., Villenave, E., 2007. Identification and quantification of ozonation products of anthracene and phenanthrene adsorbed on silica particles. Atmos. Environ. 41, 6005-6017.

Petit, J.-E., Amodeo, T., Meleux, F., Bessagnet, B., Menut, L., Grenier, D., Pellan, Y., Ockler, A., Rocq, B., Gros, V., 2017a. Characterising an intense PM pollution episode in March 2015 in France from multi-site approach and near real time data: Climatology, variabilities, geographical origins and model evaluation. Atmos. Environ. 155, 68-84.

Petit, J.-E., Favez, O., Sciare, J., Canonaco, F., Croteau, P., Močnik, G., Jayne, J., Worsnop, D., Leoz-Garziandia, E., 2014. Submicron aerosol source apportionment of wintertime pollution in Paris, France by double positive matrix factorization (PMF 2) using an aerosol chemical speciation monitor (ACSM) and a multi-wavelength Aethalometer. Atmos. Chem. Phys. 14, 13773-13787.

Petit, J. E., Favez, O., Albinet, A., Canonaco, F., 2017b. A user-friendly tool for comprehensive evaluation of the geographical origins of atmospheric pollution: Wind and trajectory analyses. Environ. Modell. Softw. 88, 183-187. 
Petit, J. E., Favez, O., Sciare, J., Crenn, V., Sarda-Estève, R., Bonnaire, N., Močnik, G., Dupont, J. C., Haeffelin, M., Leoz-Garziandia, E., 2015. Two years of near real-time chemical composition of submicron aerosols in the region of Paris using an Aerosol Chemical Speciation Monitor (ACSM) and a multi-wavelength Aethalometer. Atmos. Chem. Phys. $15,2985-3005$.

Querol, X., Alastuey, A., Viana, M., Rodriguez, S., Artíñano, B., Salvador, P., Do Santos, S. G., Patier, R. F., Ruiz, C., De la Rosa, J., 2004. Speciation and origin of PM10 and PM2. 5 in Spain. J. Aerosol Sci. 35, 1151-1172.

Reisen, F., Arey, J., 2005. Atmospheric Reactions Influence Seasonal PAH and Nitro-PAH Concentrations in the Los Angeles Basin. Environ. Sci. Technol. 39, 64-73.

Ringuet, J., Albinet, A., Leoz-Garziandia, E., Budzinski, H., Villenave, E., 2012a. Diurnal/nocturnal concentrations and sources of particulate-bound PAHs, OPAHs and NPAHs at traffic and suburban sites in the region of Paris (France). Sci. Total Environ. 437, 297-305.

Ringuet, J., Albinet, A., Leoz-Garziandia, E., Budzinski, H., Villenave, E., 2012b. Reactivity of polycyclic aromatic compounds (PAHs, NPAHs and OPAHs) adsorbed on natural aerosol particles exposed to atmospheric oxidants. Atmos. Environ. 61, 15-22.

Riva, M., Tomaz, S., Cui, T., Lin, Y. H., Perraudin, E., Gold, A., Stone, E. A., Villenave, E., Surratt, J. D., 2015. Evidence for an unrecognized secondary anthropogenic source of organosulfates and sulfonates: gas-phase oxidation of polycyclic aromatic hydrocarbons in the presence of sulfate aerosol. Environ. Sci. Technol. 49, 6654-64. 
Sandradewi, J., Prévôt, A. S. H., Szidat, S., Perron, N., Alfarra, M. R., Lanz, V. A., Weingartner, E., Baltensperger, U., 2008. Using Aerosol Light Absorption Measurements for the Quantitative Determination of Wood Burning and Traffic Emission Contributions to Particulate Matter. Environ. Sci. Technol. 42, 3316-3323.

Schauer, J. J., Rogge, W. F., Hildemann, L. M., Mazurek, M. A., Cass, G. R., Simoneit, B. R., 1996. Source apportionment of airborne particulate matter using organic compounds as tracers. Atmos. Environ. 30, 3837-3855.

Schembari, C., Bove, M. C., Cuccia, E., Cavalli, F., Hjorth, J., Massabò, D., Nava, S., Udisti, R., Prati, P., 2014. Source apportionment of PM10 in the Western Mediterranean based on observations from a cruise ship. Atmos. Environ. 98, 510-518.

Schulte, J. K., Fox, J. R., Oron, A. P., Larson, T. V., Simpson, C. D., Paulsen, M., Beaudet, N., Kaufman, J. D., Magzamen, S., 2015. Neighborhood-Scale Spatial Models of Diesel Exhaust Concentration Profile Using 1-Nitropyrene and Other Nitroarenes. Environ. Sci. Technol. 49, 13422-13430.

Schwab, J., Felton, D., Rattigan, O., L Demerjian, K., 2006. New York state urban and rural measurements of continuous PM2.5 mass by FDMS, TEOM, and BAM. Vol 56.

Sciare, J., D'Argouges, O., Sarda-Esteve, R., Gaimoz, C., Dolgorouky, C., Bonnaire, N., Favez, O., Bonsang, B., Gros, V., 2011. Large contribution of water-insoluble secondary organic aerosols in the region of Paris (France) during wintertime. J. Geophys. Res.-Atmos. 116, D22203.

Seinfeld, J. H., Pandis, S. N., 2012. Atmospheric chemistry and physics: from air pollution to climate change: John Wiley \& Sons. 
Shakya, K. M., Griffin, R. J., 2010. Secondary Organic Aerosol from Photooxidation of Polycyclic Aromatic Hydrocarbons. Environ. Sci. Technol. 44, 8134-8139.

Shrivastava, M. K., Subramanian, R., Rogge, W. F., Robinson, A. L., 2007. Sources of organic aerosol: Positive matrix factorization of molecular marker data and comparison of results from different source apportionment models. Atmos. Environ. 41, 9353-9369.

Simoneit, B. R. T., 2002. Biomass burning - a review of organic tracers for smoke from incomplete combustion. Appl. Geochem. 17, 129-162.

Simoneit, B. T., 1999. A review of biomarker compounds as source indicators and tracers for air pollution. Environ. Sci. Pollut. Res. 6, 159-169.

Srimuruganandam, B., Shiva Nagendra, S. M., 2012. Application of positive matrix factorization in characterization of PM10 and PM2.5 emission sources at urban roadside. Chemosphere. $88,120-130$.

Srivastava, D., Goel, A., Agrawal, M., 2016. Particle Bound Metals at Major Intersections in an Urban Location and Source Identification Through Use of Metal Markers. Proc. Natl. Acad. Sci., India, Sect. A. 86, 209-220.

Srivastava, D., Tomaz, S., Favez, O., Lanzafame, G. M., Golly, B., Besombes, J.-L., Alleman, L. Y., Jaffrezo, J.-L., Jacob, V., Perraudin, E., Villenave, E., Albinet, A., 2018. Speciation of organic fraction does matter for source apportionment. Part 1: A one-year campaign in Grenoble (France). Sci. Total Environ. In press. 
Stein, A. F., Draxler, R. R., Rolph, G. D., Stunder, B. J. B., Cohen, M. D., Ngan, F., 2015. NOAA’s HYSPLIT Atmospheric Transport and Dispersion Modeling System. Bull. Am. Meteorol. Soc. 96, 2059-2077.

Sternbeck, J., Sjödin, A., Andréasson, K., 2002. Metal emissions from road traffic and the influence of resuspension—results from two tunnel studies. Atmos. Environ. 36, 4735-4744.

Surratt, J. D., Kroll, J. H., Kleindienst, T. E., Edney, E. O., Claeys, M., Sorooshian, A., Ng, N. L., Offenberg, J. H., Lewandowski, M., Jaoui, M., Flagan, R. C., Seinfeld, J. H., 2006. Evidence for Organosulfates in Secondary Organic Aerosol. Environ. Sci. Technol. 41, $517-527$.

Surratt, J. D., Lewandowski, M., Offenberg, J. H., Jaoui, M., Kleindienst, T. E., Edney, E. O., Seinfeld, J. H., 2007. Effect of acidity on secondary organic aerosol formation from isoprene. Environ. Sci. Technol. 41, 5363-5369.

Tang, I. N., Tridico, A. C., Fung, K. H., 1997. Thermodynamic and optical properties of sea salt aerosols. J. Geophys. Res.-Atmos. 102, 23269-23275.

Tkacik, D. S., Presto, A. A., Donahue, N. M., Robinson, A. L., 2012. Secondary Organic Aerosol Formation from Intermediate-Volatility Organic Compounds: Cyclic, Linear, and Branched Alkanes. Environ. Sci. Technol. 46, 8773-8781.

Tomaz, S., Jaffrezo, J.-L., Favez, O., Perraudin, E., Villenave, E., Albinet, A., 2017. Sources and atmospheric chemistry of oxy- and nitro-PAHs in the ambient air of Grenoble (France). Atmos. Environ. 161, 144-154. 
Tomaz, S., Shahpoury, P., Jaffrezo, J. L., Lammel, G., Perraudin, E., Villenave, E., Albinet, A., 2016. One-year study of polycyclic aromatic compounds at an urban site in Grenoble (France): Seasonal variations, gas/particle partitioning and cancer risk estimation. Sci. Total Environ. 565, 1071-1083.

Verlhac, S., Favez, O., Albinet, A., 2013. Comparaison inter laboratoires organisée pour les laboratoires européens impliqués dans l'analyse du lévoglucosan et de ses isomères LCSQA / INERIS http://www.lcsqa.org/rapport/2013/ineris/comparaison-interlaboratoires-organisee-laboratoires-europeens-impliques-analys,

Vione, D., Barra, S., De Gennaro, G., De Rienzo, M., Gilardoni, S., Perrone, M. G., Pozzoli, L., 2004. Polycyclic aromatic hydrocarbons in the atmosphere: monitoring, sources, sinks and fate. II: Sinks and fate. Ann Chim. 94, 257-68.

Waked, A., Favez, O., Alleman, L. Y., Piot, C., Petit, J. E., Delaunay, T., Verlinden, E., Golly, B., Besombes, J. L., Jaffrezo, J. L., Leoz-Garziandia, E., 2014. Source apportionment of PM10 in a north-western Europe regional urban background site (Lens, France) using positive matrix factorization and including primary biogenic emissions. Atmos. Chem. Phys. 14, $3325-3346$.

Walgraeve, C., Demeestere, K., Dewulf, J., Zimmermann, R., Van Langenhove, H., 2010. Oxygenated polycyclic aromatic hydrocarbons in atmospheric particulate matter: Molecular characterization and occurrence. Atmos. Environ. 44, 1831-1846.

Wang, Y., Hopke, P. K., Xia, X., Rattigan, O. V., Chalupa, D. C., Utell, M. J., 2012. Source apportionment of airborne particulate matter using inorganic and organic species as tracers. Atmos. Environ. 55, 525-532. 
Watson, J. G., Zhu, T., Chow, J. C., Engelbrecht, J., Fujita, E. M., Wilson, W. E., 2002. Receptor modeling application framework for particle source apportionment. Chemosphere. 49, 1093-1136.

Yin, J., Allen, A., Harrison, R., Jennings, S., Wright, E., Fitzpatrick, M., Healy, T., Barry, E., Ceburnis, D., McCusker, D., 2005. Major component composition of urban PM 10 and PM 2.5 in Ireland. Atmos. Res. 78, 149-165.

Yttri, K. E., Schnelle-Kreis, J., Maenhaut, W., Abbaszade, G., Alves, C., Bjerke, A., Bonnier, N., Bossi, R., Claeys, M., Dye, C., Evtyugina, M., García-Gacio, D., Hillamo, R., Hoffer, A., Hyder, M., Iinuma, Y., Jaffrezo, J. L., Kasper-Giebl, A., Kiss, G., López-Mahia, P. L., Pio, C., Piot, C., Ramirez-Santa-Cruz, C., Sciare, J., Teinilä, K., Vermeylen, R., Vicente, A., Zimmermann, R., 2015. An intercomparison study of analytical methods used for quantification of levoglucosan in ambient aerosol filter samples. Atmos. Meas. Tech. 8, 125-147.

Zhang, H., Ying, Q., 2012. Secondary organic aerosol from polycyclic aromatic hydrocarbons in Southeast Texas. Atmos. Environ. 55, 279-287.

Zhang, Y., Sheesley, R. J., Schauer, J. J., Lewandowski, M., Jaoui, M., Offenberg, J. H., Kleindienst, T. E., Edney, E. O., 2009. Source apportionment of primary and secondary organic aerosols using positive matrix factorization (PMF) of molecular markers. Atmos. Environ. 43, 5567-5574.

Zhao, Y., Hennigan, C. J., May, A. A., Tkacik, D. S., de Gouw, J. A., Gilman, J. B., Kuster, W. C., Borbon, A., Robinson, A. L., 2014. Intermediate-Volatility Organic Compounds: A Large Source of Secondary Organic Aerosol. Environ. Sci. Technol. 48, 13743-13750. 
Zielinska, B., Sagebiel, J., Arnott, W. P., Rogers, C. F., Kelly, K. E., Wagner, D. A., Lighty, J. S., Sarofim, A. F., Palmer, G., 2004a. Phase and Size Distribution of Polycyclic Aromatic Hydrocarbons in Diesel and Gasoline Vehicle Emissions. Environ. Sci. Technol. 38, 25572567.

Zielinska, B., Sagebiel, J., McDonald, J. D., Whitney, K., Lawson, D. R., 2004b. Emission rates and comparative chemical composition from selected in-use diesel and gasoline-fueled vehicles. J. Air Waste Manage. Assoc. 54, 1138-50. 
Figures

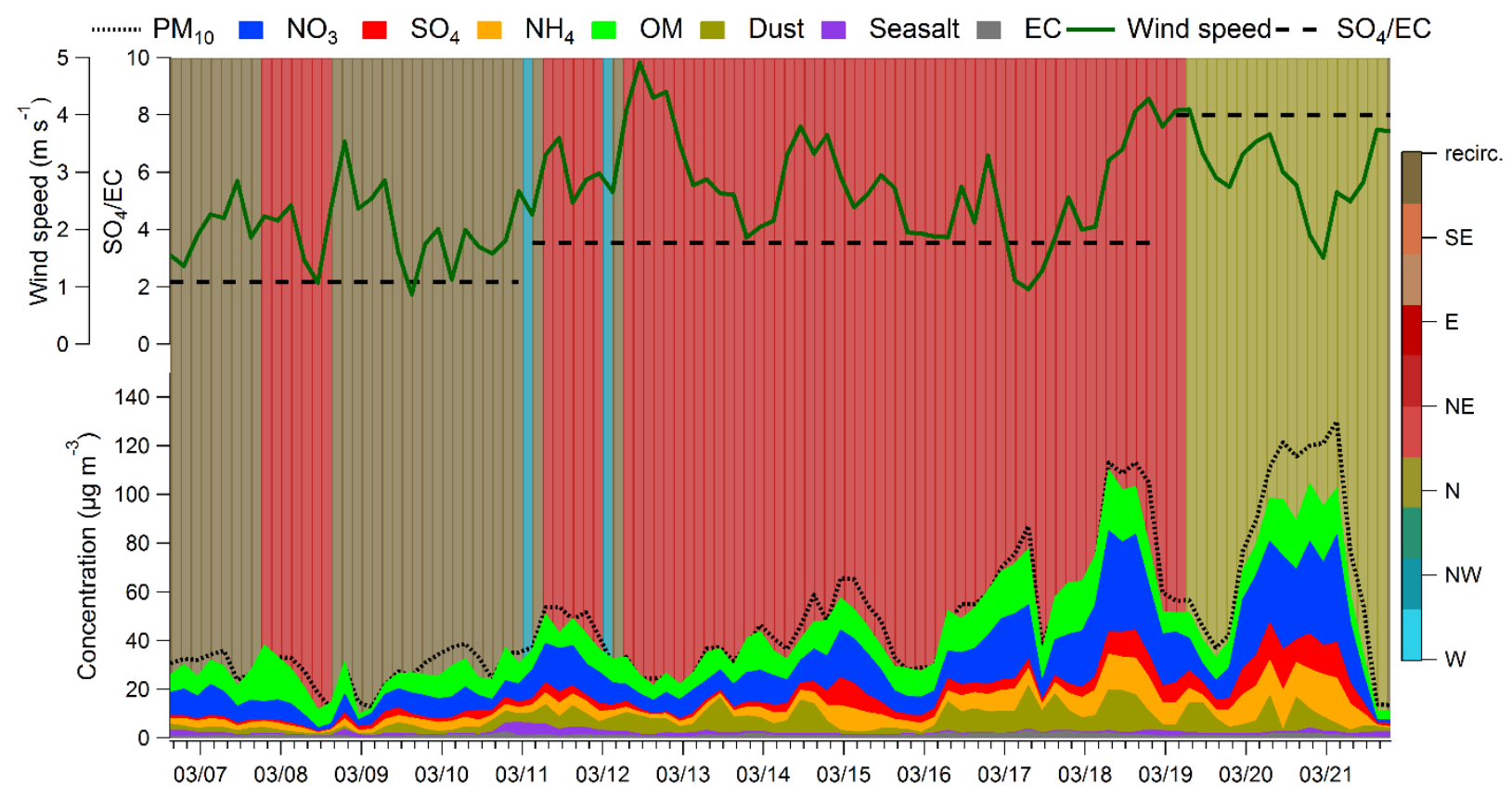

Figure 1. Temporal variation of $\mathrm{PM}_{10}$ chemical composition, $\mathrm{SO}_{4} / \mathrm{EC}$ ratio and wind speed observed at Paris-SIRTA, France (March 2015). Background colours refer to air mass clusters. Cluster analysis performed using ZeFir based on back trajectories calculated every $3 \mathrm{~h}$ with HYSPLIT model. 

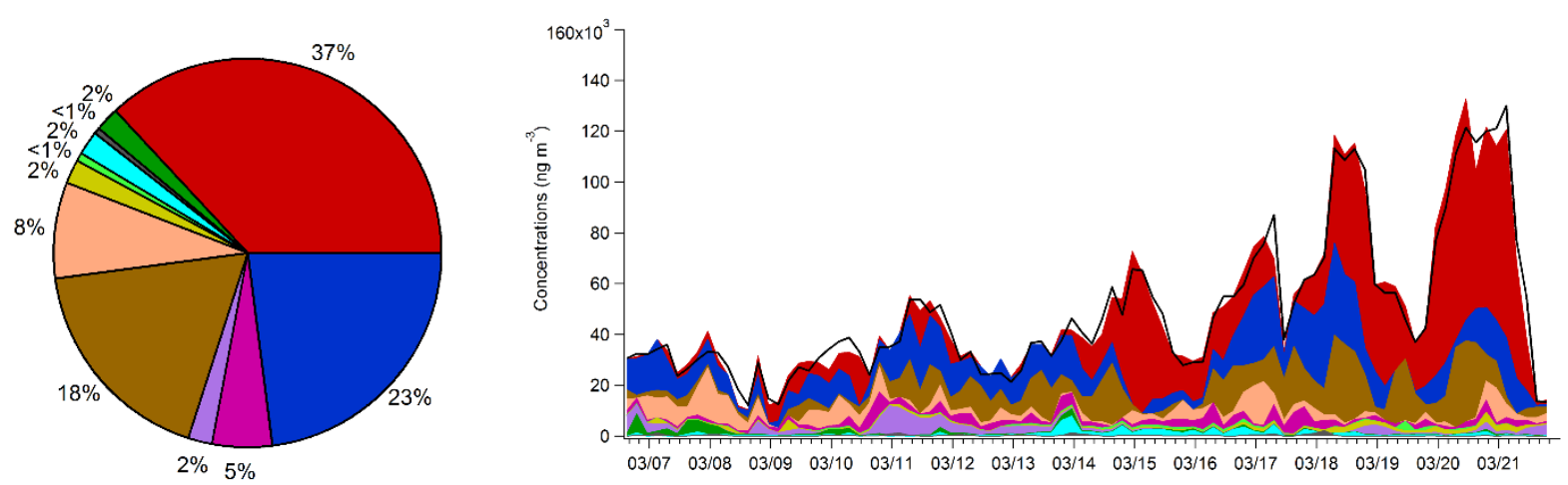

Mixed secondary aerosols Nitrate-rich factor $\square$ Primary traffic emissions Sea salt Dust

Biomass burning Biogenic SOA-1 (marine) Biogenic SOA-2 (isoprene) Anthropogenic SOA-1 (oxy-PAHs)

- Anthropogenic SOA-2 (nitro-PAHs) $\square$ Anthropogenic SOA-3 (phenolic oxidation) $-\mathrm{PM}_{10}$

Figure 2. Average contributions (left) and temporal evolution (right) of the identified sources to

$\mathrm{PM}_{10}$ mass concentrations at Paris-SIRTA, France (March 2015). 


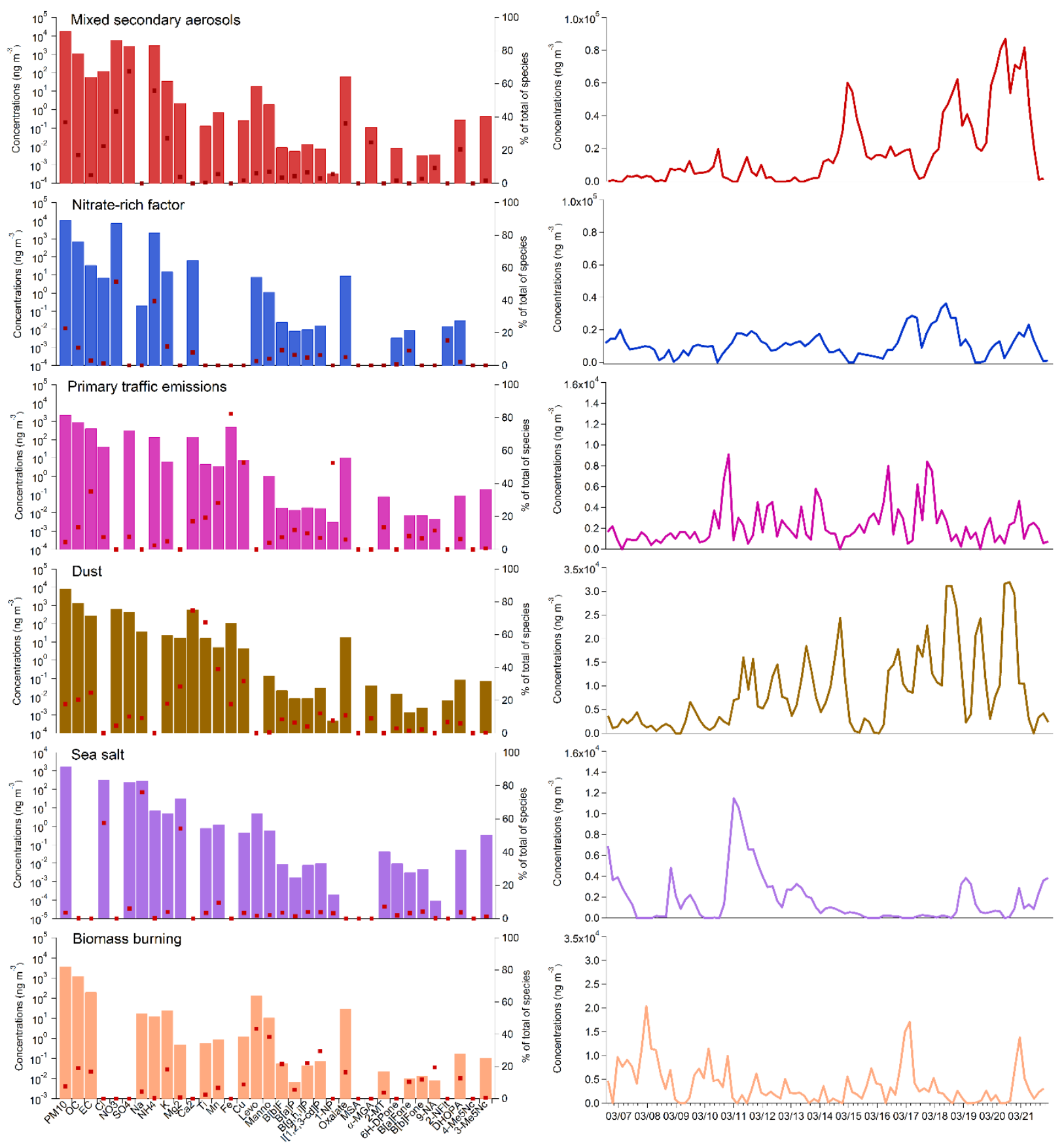

Figure 3. Source profiles and temporal evolution of mixed secondary aerosols, nitrate-rich, primary traffic emissions, dust, sea salt and biomass burning factors identified at Paris-SIRTA, France (March 2015). Coloured bars and red dots represent the concentrations and the percentages of each species apportioned in the factor, respectively. 

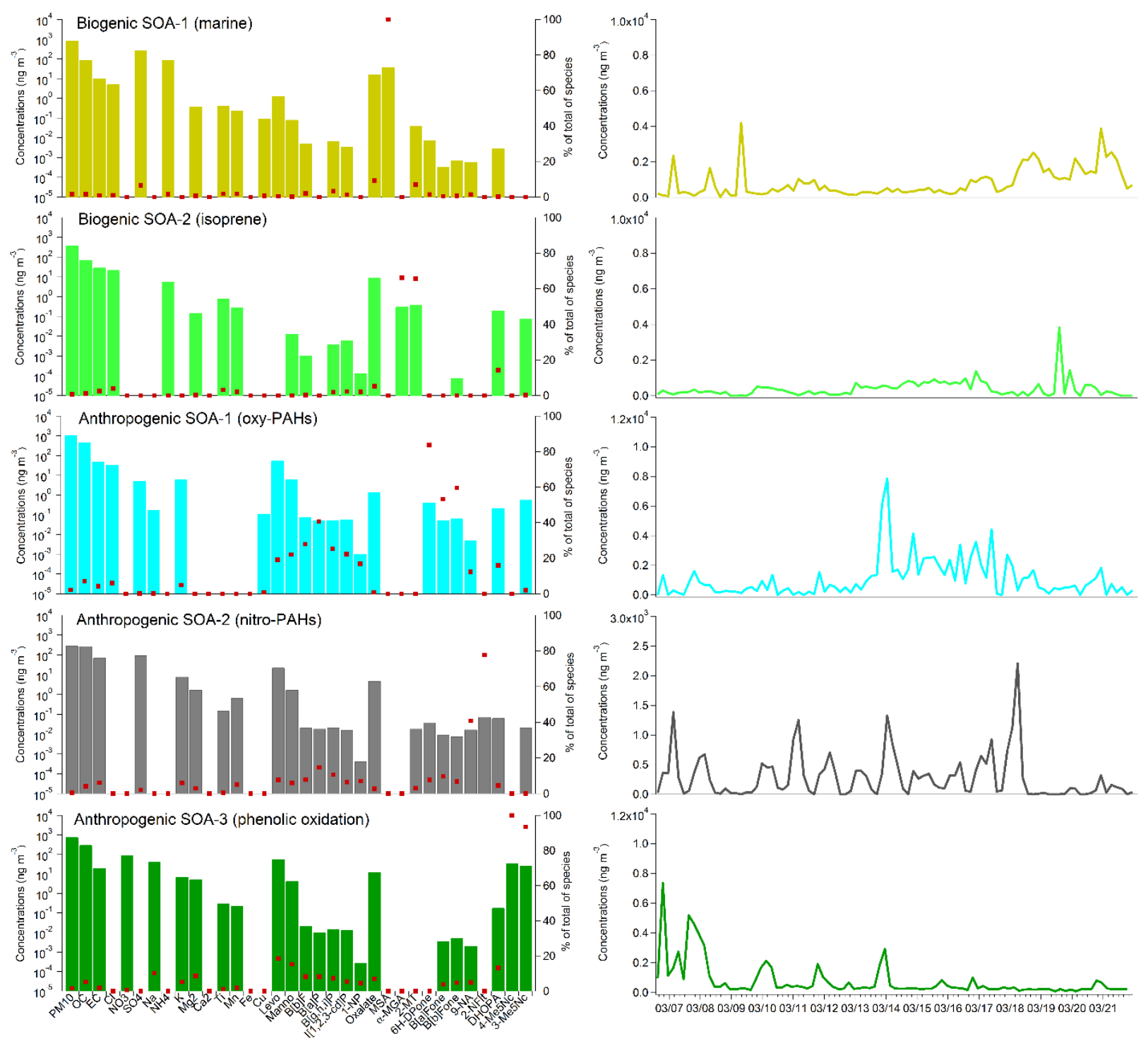

Figure 4. Source profiles and temporal evolution of biogenic SOA-1, biogenic SOA-2, anthropogenic SOA-1, anthropogenic SOA-2 and anthropogenic SOA-3 identified at Paris-SIRTA, France (March 2015). Coloured bars and red dots represent the concentrations and the percentages of each species apportioned in the factor, respectively. 


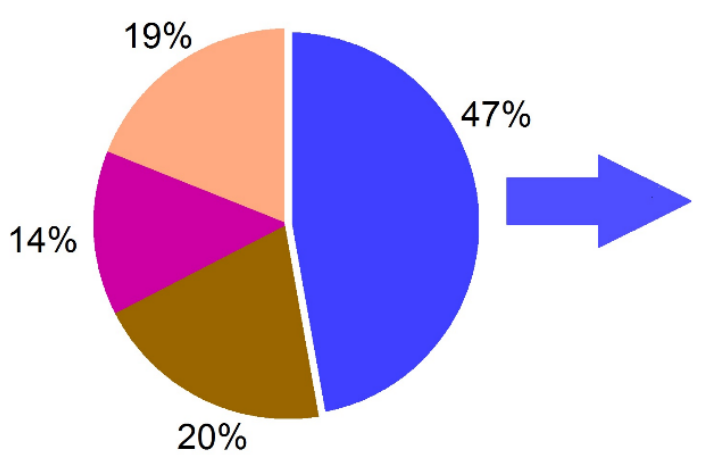

(a)

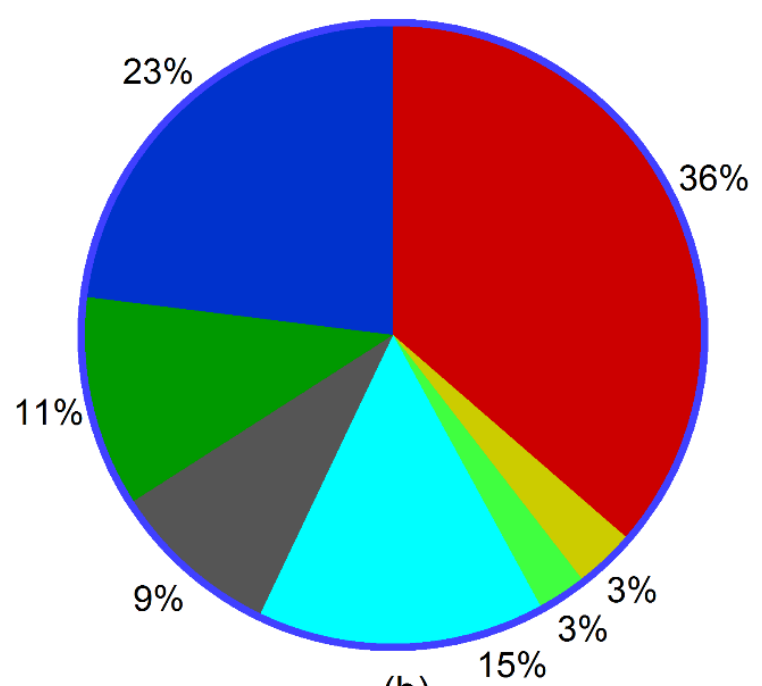

(b)

Primary traffic emissions $\square$ Dust $\square$ Biomass burning $\square$ Secondary OC $\square$ Mixed secondary aerosols

Nitrate-rich factor $\square$ Biogenic SOA-1 (marine) $\square$ Biogenic SOA-2 (isoprene)

Anthropogenic SOA-1 (oxy-PAHs) $\square$ Anthropogenic SOA-2 (nitro-PAHs) $\quad$ Anthropogenic SOA-3 (phenolic oxidation)

Figure 5. Average contributions of the identified sources to the total OC (POC + SOC) (left) and SOC (right) mass concentrations at Paris-SIRTA, France (March 2015). 

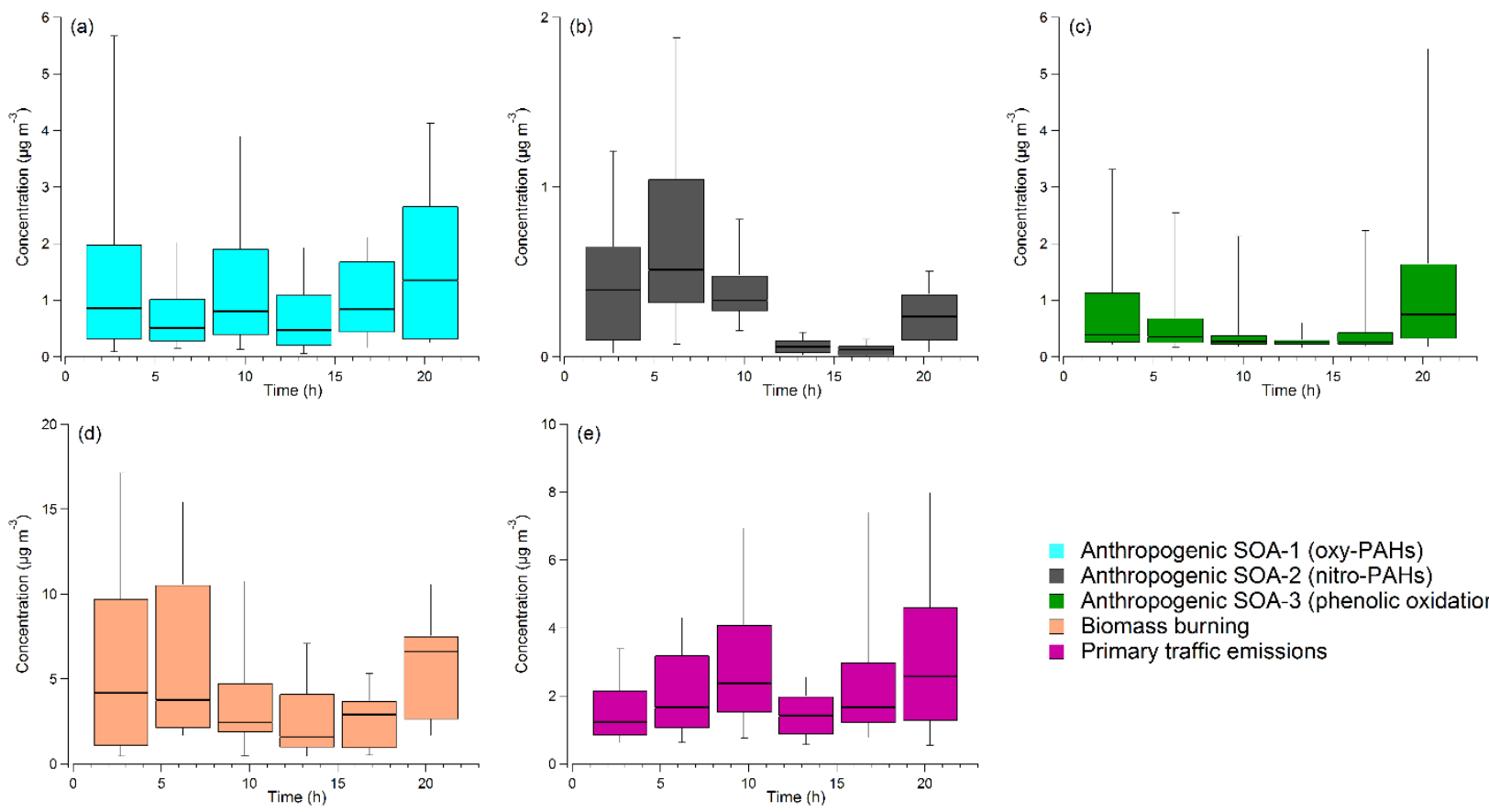

Anthropogenic SOA-1 (oxy-PAHs)

anthropogenic SOA-2 (nitro-PAHs)

Anthropogenic SOA-3 (phenolic oxidation)

- Biomass burning

- Primary traffic emissions

Figure 6. Diurnal profiles of PMF resolved anthropogenic SOA factors (1, 2, and 3), biomass burning and traffic identified at Paris-SIRTA, France (March 2015). 